\title{
Functional limitations related to foot pain in the elderly
}

\author{
Limitação funcional relacionada ao pé doloroso em idosos \\ Limitación funcional relacionada con el pie doloroso en ancianos
}

Fabiana Maria Rodrigues Lopes de Oliveira ${ }^{1}$, Keylla Talitha Fernandes Barbosa ${ }^{1}$, Saemmy Grasiely Estrela de Albuquerque ${ }^{1}$, Mayara Muniz Dias Rodrigues ${ }^{1}$, Kamyla Félix Oliveira dos Santos ${ }^{1}$, Maria das Graças Melo Fernandes ${ }^{1}$

Objective: to investigate the association between foot pain and functional disability in the elderly. Methods: descriptive study conducted among the elderly attended in a geriatric outpatient clinic of a university hospital. The sample consisted of 114 elderly who reported foot pain. Data was collected through subsidized interview, using structured instrument, covering demographic variables and the Manchester Foot Pain and Disability Index in Elderly and the Mini Mental State Examination. Results: there was a high incidence of foot pain among women and young elderly as well as significant inability to perform certain daily activities. Conclusion: it is identified the need for special attention to the health of elderly reporting foot pain, since this tends to restrict daily activities, causing decreased quality of life, immobilization and possible episodes of falls.

Descriptors: Aged; Foot; Pain; Geriatric Assessment; Nursing.

Objetivo: verificar a associação entre pé doloroso e a incapacidade funcional em idosos. Métodos: estudo descritivo, realizado entre os idosos atendidos em um ambulatório de geriatria de um Hospital Universitário. A amostra constou de 114 idosos que relataram pé doloroso. Dados coletados por meio de entrevista subsidiada por instrumento estruturado, contemplando variáveis demográficas e Índice Manchester de Incapacidade Associada ao Pé Doloroso em Idosos e o Mini Exame do Estado Mental. Resultados: verificou-se alta incidência de pé doloroso entre as mulheres e idosos jovens, bem como significativa incapacidade para realizar determinadas atividades rotineiras. Conclusão: identifica-se a necessidade de atenção especial à saúde do idoso que relata dor nos pés, visto que, este tende a restringir as atividades habituais, causando diminuição da qualidade de vida, imobilização e possíveis episódios de quedas.

Descritores: Idoso; Pé; Dor; Avaliação Geriátrica; Enfermagem.

Objetivo: verificar la asociación entre pie doloroso y discapacidad funcional en ancianos. Métodos: estudio descriptivo, realizado entre ancianos asistidos en ambulatorio de geriatría de un hospital universitario. Muestra constituida por 114 ancianos que reportaron dolor en el pie. Datos recolectados a través entrevista subsidiada por estructurada, cubriendo variables demográficas e Índice de Manchester de Discapacidad asociada a Pie Doloroso en Ancianos y Mini Examen del Estado Mental. Resultados: alta incidencia de dolor en el pie entre mujeres y ancianos jóvenes, así como incapacidad significativa para realizar determinadas actividades cotidianas. Conclusión: necesidad de prestar especial atención a la salud de ancianos que relatan dolor en los pies, ya que esto tiende a restringir actividades diarias, causando disminución de la calidad de vida, detenciones y posibles episodios de caídas.

Descriptores: Anciano; Pie; Dolor; Evaluación Geriátrica; Enfermería.

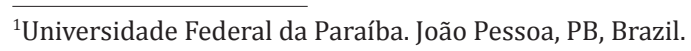

Corresponding author: Fabiana Maria Rodrigues Lopes de Oliveira

Rua Cassimiro de Abreu, 393, Apto 302 Jardim Luna, CEP: 58033-330 - João Pessoa, PB, Brazil. E-mail: fabianarodriguesenf@yahoo.com.br 


\section{Introduction}

Population aging is seen as one of the most important demographic transitions observed worldwide. It is a multifaceted issue, in which the various mechanisms are not completely understood, although several studies elucidate some of its features that have come to happen in a faster way. This event took place in Brazil after socioeconomic changes, guided by the change in the demographic profile of its population. This change has culminated in a decrease in mortality rates, increasing labor force and an increase in the number of elderly ${ }^{(1-2)}$.

In this context, Brazil is, in 2015, the seventh world position in number of elderly; projections show that, possibly in 2025, it will occupy the sixth position $^{(3)}$. With a higher concentration of elderly in the population it was observed increased incidence of chronic diseases, which can be accompanied by sequelae, which limit the functional performance and generate dependency. The presence of multiple diseases with different levels of severity can influence the performance of activities of daily living and reduce the autonomy of the elderly ${ }^{(4)}$.

Various problems that can affect this population and it is worth stressing those that impair their functional capacity. Among these are the changes in anatomical and physiological structures of the feet, which may be due to systemic diseases, disorders of gait and foot fractures that compromise the integrity of nails, skin, nerves, vessels and bony structures ${ }^{(5)}$. Such injuries generate some consequences for the life of the elderly, such as the decrease in ability to perform activities of daily living, decreased strength, balance and mobility, gait disturbance, increased risk of falls and of postural instability resulting in functional disability ${ }^{(6)}$.

Based on these considerations, the relevance of this study is confirmed by the need to know more and more about foot changes in the elderly and its association with functional disability that results in reduced autonomy and quality of life.
The results of this study will encourage the identification of the main foot problems experienced by the elderly, since the literature involving this issue is weak and scarce. In this sense, the results of this research can raise resources for professionals who deal with elderly patients carrying this problem, especially nurses, allowing the recognition of the specific characteristics of foot changes and the risks that surround them. In this context, this study aimed to determine the association between foot pain and functional disability in the elderly.

\section{Method}

It is descriptive, quantitative study conducted with elderly seen in a geriatric outpatient clinic of a university hospital in the city of João Pessoa. The sample of probabilistic type, selected through simple sampling technique. For the calculation, the following formula was considered: $\mathrm{n}=\mathrm{Z2} \mathrm{PQ} / \mathrm{d} 2$, where $\mathrm{n}=$ minimum sample size; $\mathrm{Z}=$ reduced variable; $\mathrm{P}=$ probability of finding the phenomenon studied; $\mathrm{Q}=$ $1-\mathrm{P} ; \mathrm{d}=$ desired accuracy. It is adopted $\mathrm{p}=50 \%$, and sampling error parameter of $5 \%$, and $95 \%$ confidence level. According to data from the clinic, there were 175 elderly registered in January 2013. After performing the calculations, the sample consisted of 114 individuals, chosen at random.

The elderly who reported foot pain were included as well as those with scores higher than 13 (for illiterates) and 17 (for literates) in the Mini-Mental State Examination ${ }^{(7)}$. The study excluded those with moderate/severe cognitive impairment, amputations and/or use prosthetic limbs; stroke sequelae; Parkinson's disease; lower limbs and/or spine fractures, those using wheelchair, who had impaired speech and/or hearing that would prevent them from responding to interview as well as those who did not report foot pain. The data collection instrument was applied by interviewers linked to the Group for Study and Research on Adult and Elderly Health, who have been properly trained to carry out such procedure, with 
information on the operational aspects of data collection instrument and the study objectives.

This study was conducted from June 2012 to January 2013, and data collection was held from October to December 2012, through interviews performed with a structured instrument composed of two parts. The first comprised questions about sex, age, and the second addressed the association between foot pain and functional disability using the validated and adapted version for the Portuguese language of the Manchester Foot Pain and Disability Index in Elderly ${ }^{(8)}$.

The Manchester Foot Pain and Disability Index in Elderly has nineteen statements, divided into four subscales: Nine statements on disability, five statements on pain, three statements on preoccupation and two statements on difficulty. In each statements, the elderly had to point the frequency of symptoms in the feet, in the last thirty days. If the disability was absent, the alternative "never, none of the time" was chosen. If present, one of the alternatives "Yes, on some days" or "yes on most/every day(s)" was chosen. Soon after, the points obtained by the elderly in the assessment were added, thus expressing the degree of disability evidenced. The score ranged from zero to 38 .

Data analysis was carried out in quantitative approach by using descriptive statistics for the univariate variables. Therefore, it was conducted distribution of absolute and relative frequencies for categorical variables and means with standard deviation for continuous variables. Regarding the comparison of the mean of the Manchester Foot Pain and Disability Index in Elderly between groups, bivariate analyzes were performed using the Student's t-test for independent samples, considering the normality of the data, previously tested using the Kolmogorov-Sminorv test. The Chi-square test was used to compare the main categorical variables in accordance with the objectives proposed for the study. For this purpose, we used the Statistical Package for the Social Sciences program, version 20.0, which is adequate to achieve the objectives and allows the accuracy and generalization of results.

The study project was examined and approved by the Research Ethics Committee of the University Hospital Lauro Wanderley, opinion No. 28/12, in compliance with the directives and regulations of research involving humans in force at the time of approval.

\section{Results}

As for the characterization of the sample, there was prevalence of females (85.1\%), with predominant age group of 60-69 years old (51.7\%). Regarding the score of the elderly on Manchester Foot Pain and Disability Index in Elderly test, it was found that this ranged from 5 to 38 points, with mean of 24.7 and standard deviation of 7.4. By correlating the variables, it was found that, on average, seniors who reported having foot pain had higher scores on Manchester Foot Pain and Disability Index in Elderly test ( $\mathrm{M}=$ 25.2 , SD \pm 3.18 ) than those individuals who did not have foot pain ( $M=15.43, S D \pm 6.85)$. This difference was statistically significant $\mathrm{t}(114)=-3.53, \mathrm{p}=0.001$.

In the analysis of the frequency of responses of the elderly to statements of Manchester Foot Pain and Disability Index in Elderly (Table 1), it was found that with regard to functional limitation, in the item "on most days" $78.5 \%$ of the elderly avoid walking on hard and rough surfaces, $71.1 \%$ avoid standing for a long time, $66.2 \%$ avoid walking long distances, $61.2 \%$ avoid walking outside at all, 55.4\% walk slowly, and $57.9 \%$ are concerned about the shoes they have to wear.

By correlating the occurrence of foot pain and the variables that make up the Manchester Foot Pain and Disability Index in Elderly, there was statistical significance in the following data: I do everything with discomfort $(p=0.003)$, I get irritable when my feet hurt ( $p=0.001)$, I feel self-conscious about shoes I have to wear $(p=0.002)$, I have constant pain in my foot $(p<0.001)$, My feet are more painful in the evening $(\mathrm{p}<0.001)$ and I get shooting pains in my feet $(\mathrm{p}<0.001)$. 
Table 1 - Frequency distribution of the Manchester Foot Pain and Disability Index in Elderly variables among the elderly who reported the occurrence of foot pain. $(n=114)$

\begin{tabular}{|c|c|c|c|}
\hline \multirow{2}{*}{ Variables } & Never & On some days & On most days \\
\hline & n (\%) & n (\%) & n (\%) \\
\hline I avoid walking outside at all & $18(14.9)$ & $29(24.0)$ & $74(61.2)$ \\
\hline I avoid walking long distances & $16(13.2)$ & $25(20.7)$ & $80(66.1)$ \\
\hline I don't walk in a normal way & $26(21.5)$ & $40(33.1)$ & $55(45.5)$ \\
\hline I walk slowly & $14(11.6)$ & $40(33.1)$ & $67(55.4)$ \\
\hline I have to stop and rest my feet & $36(29.8)$ & $39(32.2)$ & $46(38.0)$ \\
\hline I avoid hard or rough surfaces when possible & $3(2.5)$ & $23(19.0)$ & $95(78.5)$ \\
\hline I avoid standing for a long time & $15(12.4)$ & $20(16.5)$ & $86(71.1)$ \\
\hline I catch the bus or use the car more often & $9(7.4)$ & $58(47.9)$ & $54(44.6)$ \\
\hline I need help with housework/shopping & $32(26.4)$ & $43(35.5)$ & $46(38.0)$ \\
\hline I do everything with discomfort & $10(8.3)$ & $56(46.3)$ & $55(45.5)$ \\
\hline I get irritable when my feet hurt & $33(27.3)$ & $51(42.1)$ & $37(30.6)$ \\
\hline I feel self-conscious about my feet & $32(26.4)$ & $30(24.8)$ & $59(48.8)$ \\
\hline I feel self-conscious about the shoes I have to wear & $21(17.4)$ & $30(24.8)$ & $70(57.9)$ \\
\hline I have constant pain in my feet & $12(9.9)$ & $52(43.0)$ & $57(47.1)$ \\
\hline My feet are worse in the morning & $12(9.9)$ & $64(52.9)$ & $45(37.5)$ \\
\hline My feet are more painful in the evening & $20(16.5)$ & $44(36.4)$ & $57(47.1)$ \\
\hline I get shooting pains in my feet & $38(31.4)$ & $49(40.5)$ & $34(28.1)$ \\
\hline I am unable to carry out my previous work & $30(24.8)$ & $52(43.0)$ & $39(32.2)$ \\
\hline I no longer do all my previous activities & $28(23.1)$ & $52(43.0)$ & $41(33.9)$ \\
\hline Total & $405(100.0)$ & $797(100.0)$ & $1097(100.0)$ \\
\hline
\end{tabular}

\section{Discussion}

It was observed prevalence of female among the elderly, which is in agreement with the literature, which describes this feature as "aging feminization". In North America and Japan, currently, women live seven years longer than men, whereas in France they live about eight years longer than the opposite sex. In Brazil, the projections say that in 2020 there will be 78 men for every 100 women ${ }^{(9)}$. Regarding the distribution by age, there was predominance of the age group of 60-69 years old. These findings are similar to a study ${ }^{(6)}$ conducted on painful foot of the elderly associated with functional disability, involving 100 elderly, of which $43 \%$ were in the aforementioned age group.
As regards the association of the painful foot with functional disability, the scale ${ }^{(10)}$ measures the appearance of disabilities resulting from this event, and it was recently used in epidemiological studies and clinical trials. In epidemiology, it has been used to produce a dichotomized measure of disability. In this study, it was shown that $99.1 \%$ of seniors reported, at least on an item, difficulties in carrying out the proposed activities on most days. These results converge with findings in a research ${ }^{(11)}$ conducted with elderly residents in the city of São Paulo, which used the same instrument, showing that $70 \%$ of respondents expressed some sort of discomfort due to pain in the feet.

The mean score of Manchester Foot Pain and Disability Index in Elderly among the elderly who reported painful feet was 24.7. Among women, the 
average was 24.9, featuring greater difficulties in carrying out activities than men, who presented a mean of 23.9. Similar results were shown on a Danish study, which revealed highest means among the female elderly (16.6) compared to the male elderly (14.7) ${ }^{(12)}$. These findings are consistent with the relevant literature ${ }^{(6,10-13)}$, which show compliance that women not only develop, but also verbalize more often pain in the feet than men. This is related, among other things, to the type of shoes worn throughout life, which increase the likelihood of developing foot problems. Furthermore, women have reduced tolerance to pain when compared to the opposite sex, which makes them more likely to report this event ${ }^{(10,13)}$.

The incidence of self-reported pain in the feet showed statistically significant correlation with the Manchester Foot Pain and Disability Index in Elderly, demonstrating that elderly people who reported foot pain could present greater degree of disability. It is noteworthy that not all foot problems generate pain or functional limitations, however, people with foot pain have a lower level of well-being, as well as higher risk of decreased mobility, balance and gait cycle and may therefore be a contributing factor to functional disability and falls in the elderly ${ }^{(6,10)}$.

Concerning table 1 , it was found that the items that presented more evidence in the item "on most days" were: I avoid walking on hard and rough surfaces whenever possible (78.5\%), I avoid standing for a long time $(71.1 \%)$ and I avoid walking long distances (66.1\%). These results are consistent with those found in a Brazilian research ${ }^{(6)}$, in which the elderly involved had similar difficulties, differing only in the statement: I catch the bus, subway or use the car more often.

Despite the high prevalence of foot problems and their losses, these problems are often not perceived as the elderly consider them an inevitable consequence of aging, rather than a medical condition.
Although the association between foot pain and impaired functional capacity in older people are not well understood in the literature ${ }^{(14)}$, study in Australia says that foot problems cause significant impact on decreased quality of life and self-perceived health, concluding that the elderly need to have guaranteed access to foot treatment ${ }^{(15)}$.

By correlating the occurrence of foot pain and the variables that make up the Manchester Foot Pain and Disability Index in Elderly, there was statistical significance in the following data: I do everything with discomfort, I get irritable when my feet hurt, I am self-conscious about the shoes I have to wear, I have constant pain in the feet, My feet are more painful in the evening and I get shooting pains in my feet. Given that the foot is the only direct source of contact with the ground, when performing such tasks it is plausible to infer that the presence of pain in the feet may affect the balance, resulting in greater caution and limitation by the elderly to carry out some activities ${ }^{(13)}$.

\section{Conclusion}

The results show that the occurrence of functional limitations associated with pain in the feet was high among the elderly investigated, being more frequent in female individuals aged from 60 to 69 years old. As for the Manchester Foot Pain and Disability Index in Elderly, statements that showed greater evidence in the item "on most days" were: I avoid walking on hard and rough surfaces whenever possible, I avoid standing for long time and I avoid walking distances.

Among the limitations of this study, it is emphasized that it characterizes only a local reality. However, it is observed that these research results are relevant as they instigate reflection on health professionals and on the elderly, in order to raise awareness to the magnitude of this event, its high 
prevalence and consequences on the quality of life of seniors. It is therefore recommended investigation on foot pain and its association with functional limitations in other scenarios in order to verify the dimension and significance of this event in the life of the elderly in their various contexts.

The identification of factors associated with foot pain is very important to the development of strategies for the prevention of limitations, to early detection and monitoring of installed disabilities, as well as to prevent decreased mobility, balance, gait and consequently the occurrence of falls, which is characterized as one of the most debilitating events in this population. It is worth noting the importance of having special health care for the elderly who report foot pain, as this condition tends to restrict their usual activities, causing decreased autonomy and quality of life.

\section{Collaborations}

Oliveira FMRL and Barbosa KTF contributed to the conception, design, analysis and interpretation of data. Albuquerque SGE and Rodrigues MMD contributed to final approval of the version to be published. Santos KFO and Fernandes MGM contributed to writing the article and relevant critical review of the intellectual content.

\section{References}

1. Teixeira INDO, Guariento ME. Biologia do envelhecimento: teorias, mecanismos e perspectivas. Ciênc Saúde Coletiva. 2010; 15(6):2845-57.

2. Oliveira FMRL, Fernandes MGM, Barbosa KTF, Pereira MA, Santos KFO, Nunes TB. Characterization of trauma in elderly assisted in a mobile emergency care service. Rev Rene. 2013; 14(5):945-50.
3. Fernandes MGM, Oliveira FMRL, Barbosa KTF, Rodrigues MMD, Bastos RAA. Evaluation of fear of falling in elderly in ambulatory care. Rev Enferm UFPE on line [periódico na Internet]. 2013 [citado 2015 maio 19];7(4):1160-6. Disponível em: http://www.revista.ufpe.br/revistaenfermagem/ index.php/revista/article/download/4069/5942

4. Tavares DMS, Dias FA. Capacidade funcional, morbidades e qualidade de vida de idosos. Texto Contexto Enferm. 2012; 21(1):112-20.

5. Ferrari SC, Santos FC, Araújo MSL, Cendoroglo MS, Trevisani VFM. Patologias no pé do idoso. Rev Bras Ciênc Envelh Hum. 2009; 6(1):106-18.

6. Prato SCF, Santos FC, Trevisani VFM. Pé doloroso do idoso associado à incapacidade funcional. Rev Dor. 2012; 13(1):18-24.

7. Bertolucci PHF, Brucki SMD, Campacci SR, Juliano Y. O Mini-Exame do Estado Mental em uma população geral: impacto da escolaridade. Arq Neuropsiquiatr. 1994; 52(1):1-7.

8. Ferrari SC, Santos FC, Guarnieri AP, Salvador N, Correa AZAH, Hala AZA, et al. Índice manchester de incapacidade associada ao pé doloroso no idoso. Rev Bras Reumatol. 2008; 48(6):335-41.

9. Chaimowicz F. Saúde do idoso. Belo Horizonte: NESCON-UFMG; 2013.

10. Van der Zwaard BC, Elders PJM, Knol DL, Gorter KJ, Peeraer L, Van der Windt DA, et al. Treatment of forefoot problems in older people: study protocol for a randomised clinical trial comparing podiatric treatment to standardised shoe advice. J Foot Ankle Res [Internet]. 2011 [cited 2014 jan 10]; 4(11):3-8. Available from: http://www. ncbi.nlm.nih.gov/pmc/articles/PMC3080289/ pdf/1757-1146-4-11.pdf

11. Marin MJS, Maciel MC. Caracterização dos problemas relacionados aos pés de idosos de uma comunidade em município do interior do Estado de São Paulo. Rev Bras Geriatr Gerontol. 2014; 17(2):243-53. 
12. Pedersen CK, Samsoe BD, Garrow AP, Waehrens EE, Bliddal H, Christensen R et al. Development of a danish language version of the Manchester Foot Pain and Disabilty Index: repoducibility and construct validity testing. Pain Res Treat. [Internet] 2013 [cited 2014 Jan 10]; 1:2-9. Available from: http://www.hindawi.com/ journals/prt/2013/284903/

13. Menz HB, Dufour AB, Casey VA, Riskowski JL, McLean RR, Katz P, et al. Foot pain and mobility limitations in older adults: The Framingham Foot Study. J Gerontol. 2013; 68(10):1281-5.
14. Kavlak Y, Demirtas RN. Effect of foot problems on foot function in elderly men. Turkish J Geriatr. 2010; 13(3):191-6.

15. Kaoulla P, Frescos N, Menz HB. A survey of foot problems in community-dwelling older Greek Australians. J Foot Ankle Res [Internet] 2011 [cited 2015 May 19]; 4(1):23. Available from: http:// www.jfootankleres.com/content/pdf/17571146-4-23.pdf 